\title{
Development of Two Stroke Double Power Ecological Engine with Spark Assisted Compression Ignition in Lean Mixture
}

\author{
Iwan Harianton ${ }^{1,3}$, Iman Kartolaksono Reksowardojo ${ }^{2}$, Noval Lilansa ${ }^{3}$, Ayi Ruswandi ${ }^{3}$, \\ Beny Bandanajaya ${ }^{3}$, Suwadi Suparlan ${ }^{3}$ \\ ${ }^{1}$ IC Engine, Faculty of Mechanical and Aerospace Engineering-Bandung Institute of Technology, Indonesia \\ ${ }^{2}$ Combustion Engine and Propulsion System Laboratory \\ ${ }^{3}$ RAPID Research Group on IC Engine-Directorate General of Higher Education, Indonesia
}

Email address:

iwan_harianton@yahoo.com (I. Harianton)

\section{To cite this article:}

Iwan Harianton, Iman Kartolaksono Reksowardojo, Noval Lilansa, Ayi Ruswandi, Beny Bandanajaya, Suwadi Suparlan. Development of Two Stroke Double Power Ecological Engine with Spark Assisted Compression Ignition in Lean Mixture. International Journal of Energy and Power Engineering. Vol. 4, No. 2, 2015, pp. 118-122. doi: 10.11648/j.ijepe.20150402.22

\begin{abstract}
Two stroke engine is almost left out by automotive industry in urban development due to several unsolved problems including higher pollutant, fuel consumption, and impractical oiling in the combustion chamber. However, it still promotes an unforgettable advantage in generating rapid potential power twice as much as it does in the four stroke engine. This paper is one of the series research publications on the two stroke double potential power ecological engine with spark assisted compression ignition, which can maintain lower emission, better fuel consumption and practicality of the fuel type, while at the same time improve the thermal efficiency of the double power generation. Technical finding on the development has been reserved for certain purpose; therefore, such material will be presented on the basis of conceptual design to qualify for academic publication. The design of Double Power Ecological Engine had been published as it is stated in the first reference, so that some detail thermodynamic consideration will not be rewritten. The design of new development including managing steps of combustion cycle, controlling the air-fuel ratio, introducing new way of eliminating knock limit, and improving thermal efficiency will be described.
\end{abstract}

Keywords: Combustion Cycle, Air-Fuel Ratio, Direct Injection, Knock Limit, Thermal Efficiency

\section{Introduction}

The most common engine type used in the commercial vehicles today is dominated by four-stroke reciprocating engines. It is a well-known engine type that promotes better fuel economy, lower hydrocarbon emissions, higher reliability, wider power band, less vibration and cooler engine temperature. The four-stroke engine is configured in a massive engine block that requires more components, more weight, lower mechanical efficiency and less power. The alternative is the two-stroke engine, which is simpler in design, less components, lighter weight, less complicated cooling system and generate twice as much power as it is of the four-stroke engine but it produces higher hydrocarbon emissions, poor fuel economy, hotter engine temperature, less reliable, narrow power band and requires frequent servicing.
The DPE engine design adopts two-stroke reciprocating design principle of internal combustion engine with wider span of power band, lower emission, higher efficiency while the combustion cycle occurs in every rotation. It is a new configuration of two-stroke engine designed to promote firing in every engine rotation (Harianton, et al., 2014), which theoretically promotes double power output compared to the most common four-stroke engine available commercially. However, due to frequent combustion, this DPE engine is expected to generate higher engine temperature so that it requires special outer shape geometry and scavenging process inside the combustion chamber to let larger air flow contact suitable for rapid power generation such as racing engine or for airplane application. 
The prototype of DPE engine has been dry run in a non combustion phase to allow air flow from supercharge inlet connector to the combustion chamber. However, since the design only allow air charge of 1,17 atmosphere, the amount of air always fall in the reach mixture, verified by the equation $1,2,3,4,5$. Therefore, alternative design has been developed to make sure the stoichiometric mixture or lean mixture will be achieved.

In the present of Oxygen and time, hydrocarbon fuel can be fully oxidized, which we familiar with the stoichiometric mixture (st). In such mixture, combustion will convert fuel to $\mathrm{CO}_{2}$, while some hydrocarbon convert to water, $\mathrm{H}_{2} \mathrm{O}$. The Nitrogen on air, which is around $79 \%$, will not react in the lower temperature combustion, because it is one of the Innert Gas (Pischinger and Klell 2008).

$$
\begin{gathered}
\mathrm{C}_{\mathrm{x}} \mathrm{H}_{\mathrm{y}} \mathrm{O}_{\mathrm{z}}+(\mathrm{x}+\mathrm{y} / 4-\mathrm{z} / 2)\left(\mathrm{O}_{2}+3.76 \mathrm{~N}_{2}\right) \times \mathrm{CO}_{2}+\mathrm{y} / 2 * \mathrm{H}_{2} \mathrm{O}+3 . \\
76(\mathrm{x}+\mathrm{y} / 4-\mathrm{z} / 2) \mathrm{N}_{2}
\end{gathered}
$$

For the complete combustion, it requires certain amount of Oxygen to meet hydrocarbon, so with the air provides $21 \%$ of Oxygen, the amount of air can be calculated by equation 2 and 3 as follows:

$$
\begin{gathered}
\mathrm{O}_{2 \mathrm{st}}=(\mathrm{x}+\mathrm{y} / 4-\mathrm{z} / 2)\left[\mathrm{kmol} \mathrm{O}_{2} / \mathrm{kmol} \text { fuel }\right] \\
\mathrm{L}_{\mathrm{st}}=(1 / 0.21) \mathrm{O}_{2 \mathrm{st}}=4.76 \mathrm{O}_{2 \mathrm{st}}[\mathrm{kmol} \mathrm{air} / \mathrm{kmol} \text { fuel }]
\end{gathered}
$$

Furthermore, the stoichiometric condition where, air-fuel mixture ratio equal to $1(\lambda=1)$, and the fuel is liquid, then mass fraction of carbon $\mathrm{C}(\mathrm{kg} / \mathrm{kg}$ fuel), hydrogen $\mathrm{H}$, oxygen $\mathrm{O}$ are used instead of molar masses. So that the equation (2) becomes (4), and equation (3) becomes (5), as follows:

$$
\begin{aligned}
& \mathrm{O}_{2 \text { st }}=28.9(\mathrm{C} / 12.01+\mathrm{H} / 4.03-\mathrm{O} / 32)\left[\mathrm{kg} \mathrm{O}_{2} / \mathrm{kg} \text { fuel }\right] \\
& \mathrm{L}_{\mathrm{st}}=137.8(\mathrm{C} / 12.01+\mathrm{H} / 4.03-\mathrm{O} / 32)[\mathrm{kg} \text { air } / \mathrm{kg} \text { fuel }]
\end{aligned}
$$

Such equation will be used to control the amount of air in the combustion chamber to assure $\lambda=1$ or leaner.

In practical point of vew, for gasoline or diesel fuels, the air required will be around $14.5 \mathrm{~kg}$ air $/ \mathrm{kg}$ fuel at the Stoichiometric combustion. Therefore, for leaner combustion set up, the amount of air will be more than $14,5 \mathrm{~kg}$ air $/ \mathrm{kg}$ fuel. However based on the theoretical number of lean mixture, it should not go beyond $\lambda=1.4$ as it reaches the upper ignition limit even though it delivers higher thermal efficiency (Pischinger and Klell 2008).

Spark Assisted Compression Ignition (SACI)

\subsection{Introduction of SACI}

Compression ignition is the diesel combustion principle where air is compressed in a higher compression ratio above
20, where diesel fuel is injected in a nearly top dead center to perform combustion. SACI in gasoline engine is relatively new development where direct injection technology become available for gasoline fuel (Yilmar, et. al. 2014). Such technology has improved the performance of SI engine by minimizing knock limit which commonly occurs in lower research octane number fuel. Knock limit in gasoline engine is the early combustion due to increasing pressure and heat in the chamber before top dead center, where the energy generated become significant will make the engine vibrate harder and decreasing the power. Therefore, knock limit is one of the problem in SI engine.

SACI eliminate the possibility of generating knock limit, because it only compress air. However, the original SACI technology has limited time to mix oxygen with the hydrocarbon in the chamber will generate incomplete combustion, which creates shoots noticeable by darker exhaust gas and certainly contain high level of pollutants. The problem in the combustion chamber related to air fuel mixture and managing knock limit will be the central idea of the development. Furthermore, the timing to make sure air fuel mixture in $\lambda \geq 1$ will be the measure of the success of the development.

\subsection{The Research and Development Focus}

The above problems also occur in the four-stroke direct injection engine at low speed but at most of the time for every cycle is significantly different starting from the intake air charge stroke from TDC to BDC, compression stroke started by injecting fuel so that from BDC to TDC where air and fuel already inside with the compression ratio upto $\varepsilon=$ 12 , combustion stroke from TDC to BDC where work is generated, and exhaust stroke from BDC to TDC where all exhaust gas expelled from the combustion chamber, then ready for the new combustion cycle.

In the two-stroke DPE-SACI engine time is rather short, in fact only half of the four-stroke cycle required to complete the process. So that the time is very critical and so managing the cycle will be very distict to the above existing system. To make all detail description on the table, the two-stroke DPESACI engine works as detailed in the table 1. Each step will be very important to make sure the advantage of the engine can be assured in opposed to the existing two-stroke engine that people tend to avoid due to its weaknesses. Certainly, some of the problems have not been covered in this paper due to complexity of the formula that may not be possible to be published in a single journal. However, such finding will be soon carried over to public for academic contribution to the society. 
Table 1. Combustion cycle of 2-stroke DPE-SACI Engine.

\begin{tabular}{|c|c|c|}
\hline Combustion Cycle & Designed action to take place & Significancy of the design \\
\hline Start at $\mathrm{BDC}$ to $30^{\circ}$ & upercharger Clean the Combustion Chamber & Clean the shoot remain \\
\hline From $30^{\circ}$ to $45^{\circ}$ & $\begin{array}{l}\text { Turbocharger clean further the Combustion Chamber through } \\
\text { intelligent valve } \\
\text { At the end of } 45^{\circ}, 25 \% \text { fuel injected on } \lambda>1.4 \text { and continue to } \\
\text { open for other } 45 \% \text { fuel to } 90^{\circ} \text { position. }\end{array}$ & $\begin{array}{l}\text { Totally clean shoot remain } \\
\text { Better meet } \mathrm{O}_{2} \text { and } \mathrm{HC} \\
25 \% \text { fuel injected increase the chamber } \\
\text { temperature }\end{array}$ \\
\hline $\begin{array}{l}\text { From } 45^{\circ} \text { to } 90^{\circ} \text { (Turbulence air flow } \\
\text { through inlet manifold and valve } \\
\text { shape) }\end{array}$ & $\begin{array}{l}\text { Turbocharger fill the combustion chamber so that } \lambda \geq 1 \\
\text { stoichiometric or lean } \lambda<1.4 \text { on calculated } 100 \% \text { fuel supply. } \\
45 \% \text { fuel injected on } \lambda>1.4 \text { should be fulfilled before } 90^{\circ} \\
\text { position. } \\
\text { Direct Injection and lean mixture will totally avoid knock } \\
\text { limit }\end{array}$ & $\begin{array}{l}\text { Lean mixture improve thermal efficiency } \\
45 \% \text { fuel injected for better meet } \mathrm{O}_{2} \text { and } \mathrm{HC} \\
\lambda>1.4 \text { above upper combustion limit }\end{array}$ \\
\hline From $90^{\circ}$ to $170^{\circ}$ & $\begin{array}{l}\text { SACI (Turbulence air flow through air compression with } \\
\text { piston shape) } \\
30 \% \text { fuel injected to make } 1 \leq \lambda<1.4\end{array}$ & $\begin{array}{l}\text { Further knock limit eradication by E20 and } \\
\lambda>1.4 \\
\text { Better meet oxygen \& hydrocarbon }\end{array}$ \\
\hline From $170^{\circ}$ to TDC & Spark Ignition at TDC & To maximize power at TDC \\
\hline From TDC to $315^{\circ}$ & Work take place & Transfer work to torque \\
\hline From $315^{\circ}$ to $330^{\circ}$ & Exhaust gate open geometrically & Naturally blow exhaust gas \\
\hline From $330^{\circ}$ to $\mathrm{BDC}$ & Supercharger further clean the combustion chamber & $\begin{array}{l}\text { Clean exhaust gas from the combustion } \\
\text { chamber }\end{array}$ \\
\hline
\end{tabular}

\subsection{Supercharger Cleans Combustion Chamber}

The design of cleaning combustion chamber occurs from $\mathrm{BDC}$ to $30^{\circ}$ crankshaft rotation using supercharger where blower connected to the crankshaft and some of the air are trapped to blow the combustion chamber through conical channel so that intake pressure will rise about $17 \%$; however, the design is only to make air cleaning in the chamber faster. Inside the chamber the air will be processed through piston head shape so that the turbulence effect will be generated. The computational fluid dynamic software will be used to optimize the air turbulency, which will be publish in separate paper on DPE-SACI air flow design for combustion cycle optimization.

\subsection{Turbocharger Through Intelligent Valve}

Turbocharger works from $30^{\circ}$ to $45^{\circ}$ of crankshaft rotation in combination with intelligent valve to further clean combustion chamber. The design of curved manifold and rotating valve geometry will make air rotated in the chamber, which creates necessary turbulency. The turbocharger mechanism uses exhaust gas to rotate the turbine blade while on the other end of the turbine shaft connected to the compressor which push the fresh air into combustion chamber. The effective blow will be controlled by the intelligent valve opening that receive signal from the throttle input. At $45^{\circ}$ crankshaft rotation, exhaust manifold is closed, and $25 \%$ to $70 \%$ of fuel injected to increase temperature of the chamber and also to make early air-fuel mixture in the chamber. Knocking will not occurs due to two reasons, one is because $\lambda>1.4$ and two using higher RON fuel of E20 or Natural Gas.

As the crankshaft continue to rotate from $45^{\circ}$ to $90^{\circ}$, the valve opening continue to supply air from turbo charger so that when $100 \%$ fuel supply of the throttle requirement, airfuel ratio falls between $1<\lambda<1$.4. Fine tune on $\lambda$ could be set through Electronic Control Unit for driving purpose. The mass of air required based on the setted $\lambda$, between 1 to 1.4. The detail air mass will be equivalent to the length of time of the valve opening starting from $45^{\circ}$ to around $90^{\circ}$ of the piston movement.

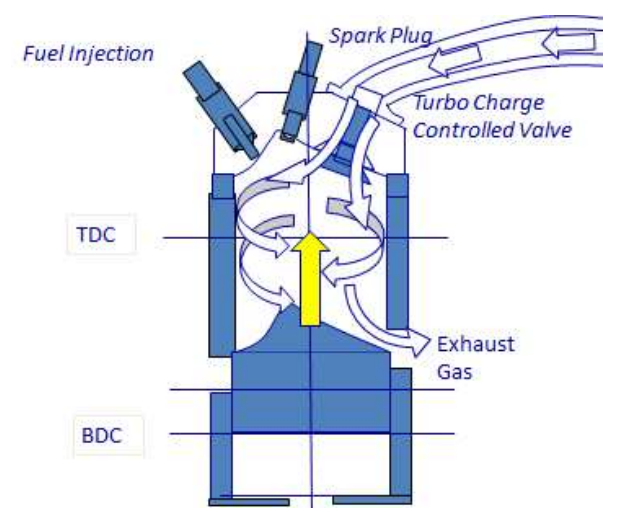

Figure 1. Turbo Charge Cleaning Combustion Chamber.

To make calculation of the air requirement for stoichiometric air fuel mixture $\lambda=1$, then $14.5 \mathrm{~kg}$ air for $1 \mathrm{~kg}$ fuel. The top speed of $6,000 \mathrm{rpm}$, will require $0.005 \mathrm{~kg}$ fuel injected (Harianton, et al., 2014); then, there will be 0.0725 $\mathrm{kg}$ air required in the stoichiometric condition. With the density of air at atmospheric pressure and $30^{\circ} \mathrm{C}$ equal to $1.165 \mathrm{~kg} / \mathrm{m}^{3}$, then $0.062238 \mathrm{~m}^{3}$ air required.

Then, based on the top speed above and the area opening in equation 6 , then $\mathrm{A}=0.00006 \mathrm{~m}^{2}$, then with the design of opening from $45^{\circ}$ to $90^{\circ}$ of crankshaft rotation at the top speed $6,000 \mathrm{rpm}$. Equation 7 give compressor pressure to deliver adequate air in the chamber; while, at the top speed $6,000 \mathrm{rpm}$ and position at $45^{\circ}$ to $90^{\circ}$, compression ratio equal to 3.99 atmosphere, then P2 should be around 4-6 Atmosphere only.

Area of the valve opening:

$$
A=\pi / 4\left(D^{2}-d^{2}\right)
$$


Design valve geometry: $D=12 \mathrm{~mm} ; \mathrm{d}=8 \mathrm{~mm}$

$$
\mathrm{P}_{1} \mathrm{~V}_{1}=\mathrm{P}_{2} \mathrm{~V}_{2} ; \text { simplified }
$$

where $\mathrm{P}_{2}$ will be the requirement of the compressor.

The working compressor selected having 4-6 atmosphere, and it will be operated under ECU devices.

At the $90^{\circ}$ of crankshaft rotation, fuel injection should reach $70 \%$ of the fuel volumetric requirement while the remaining $30 \%$ will be injected at around $170^{\circ}$ position so that better air-fuel mixture will be assured.

\subsection{Direct Injection of DPE-SACI Engine}

There are three type of direct injection parts available in the market, DPE-SACI Engine will use on of those type, they are named cam injector, common rail system injector, and servo injector. DPE-SACI Engine will use servo injector based on the practicality of the electronic control system that is available to control currect feeding to the servo switch. Figure 2 is taken from (Rakowski, et.al 2012) servo injector and figure 3 the injector nozzle design.



Figure 2. Servo injector ans nozzle design.

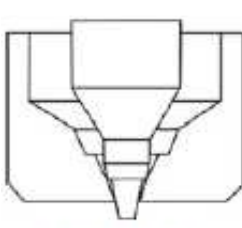

pintle nozzle

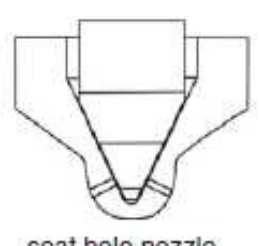

seat hole nozzle

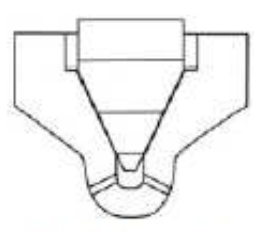

blind hole nozzle
Figure 3. injector nozzle design.

Pintle nozzle is the simplest nozzle design and the safest nozzle from shoot remain in the operation, but it is the poorest spray formation from all those option. Seat hole and blind hole nozzles are more difficult to make but they are the two best spray results of all kind. However, blind hole nozzle is more riskying option due to open space inside the spray hole, which can be build up shoot inside the spray hole. Therefore, seat hole nozzle will be use as a primary nozzle for DPE-SACI Engine.

The Electronic Control Unit will deliver command at the position $45^{\circ}$ to $90^{\circ}$ to fill $70 \%$ of the fuel and $170^{\circ}$ for another $30 \%$ fuel, so in the top speed of $6,000 \mathrm{rpm}$, injector will feed combustion chamber start at the $45^{\circ}$ for some 2 milliseconds and open agin in the interval of 3.47 milliseconds at $170^{\circ}$ for less than 1 milliseconds opening. The servo injector is capable of delivering fuel by opening and closing nozzle in 0.7 milliseconds so that the design of DPE-SACI injector can be accommodated.

\subsection{Final SACI Stroke}

Crankshaft rotation continue from $90^{\circ}$ to $170^{\circ}$ for complete SACI stroke, where $70 \%$ of fuel meet with $100 \%$ air requirement or in the lean mixture $1<\lambda<1.4$ so that such fuel injection management will eliminate knock limit and all $70 \%$ fuel meet its oxygen couple on the swirl air condition. Therefore, compression ratio can be designed higher than the 4-stroke gasoline engine. Fuel injected in three stages is also in favour to the engine vibration as the combustion will take place gradually while complete combustion will be done just before TDC by injecting the last $30 \%$ of fuel at $170^{\circ}$ of crankshaft rotation. Higher compression ratio will increase thermal efficiency of the engine, it is expected to reach $40 \%$ to $45 \%$ which will be published later.

\subsection{Spark Ignition at the TDC}

Based on the thermodynamic law, work will be maximum when it occurs at the highest piston position and it is released at the lowest exhaust temperature. Then, by increasing compression ratio to 12 , and thermal efficiency $40 \%$, the power will reach $295.63 \mathrm{~kW}$, higher than the original design which could reach up to $280,21 \mathrm{~kW}$ (Harianton, et al., 2014). The development has changed the piston diameter to $72 \mathrm{~mm}$ and the length of stroke $85.96 \mathrm{~mm}$. The torque $1,176 \mathrm{Nm}$ at the top speed of $6,000 \mathrm{rpm}$.

\subsection{SACI Generates Power}

Work is generated from TDC to $315^{\circ}$, producing power of $295.63 \mathrm{~kW}$ with the torque at $1,176 \mathrm{Nm}$ at the top speed of $6,000 \mathrm{rpm}$. The performance of the engine will be verified under standard test SNI 0119:2009 Performans test of reciprocating internal combustion engine for general use. The standard covers test method of internal combustion engines to stipulate power, gas consumption and oil consumption to establish performance of compression ignition engines such testing can be done at standard condition or in motor operating condition reference condition and stipulated as total barometer pressure $\operatorname{Pr}=100 \mathrm{Kpa}\left(100 \mathrm{KV} / \mathrm{m}^{2}\right)$, temperature $\mathrm{T}_{\mathrm{r}}=300{ }^{\circ} \mathrm{K}\left(27^{\circ} \mathrm{C}\right)$ and relative moisture of $60 \%$.

\subsection{Exhaust Gas Open}

As the crankshaft continue to rotate from $315^{\circ}$ to $330^{\circ}$, the exhaust gate open to blow down the exhaust gas. So that the combustion chamber that work in high pressure will blow the gas out through exhaust manifold. The exhaust gas is designed to rotate turbine for turbocharger on the other hand. Turbocharger is design to blow fresh air into combustion chamber with two purposes such that to final clean the exhaust gas and to fill the combustion chamber with fresh air. 


\subsection{Supercharger Purpose}

Super charger that is inslalled directly to the crankshaft will start when the engine begin. Supercharger is design to make sure the working temperature of the engine between 80 ${ }^{\circ} \mathrm{C}$ to $160{ }^{\circ} \mathrm{C}$ in land user, about $20{ }^{\circ} \mathrm{C}-50{ }^{\circ} \mathrm{C}$ cooler when it is used for small aircraft application and also the clean the combustion chamber through conical tunnel. The cooling system has been designed to blow air at $1.3 \mathrm{~m}^{3}$ per second.

\section{Conclusion}

DPE-SACI engine has been reviewed to have four improvement results including increasing compression ratio, eliminating knock limit, inventing intelligent valve, and redesign of swirling turbo charge in addition to the original advantages including double potential power, cleaner emission, and no possibility of fuel exhausted before combustion as the common mistake of the two-stroke engine.

Increasing compression ratio will improve the engine thermal efficiency and so improving the work generated from the engine. The increasing compression ratio was followed by the design of piston head and combustion chamber geometry.

Knocking is generally combustion that occur before spark ignite, it lower the power and higher vibration due to the reverse forces occur too early. By using E20 blended fuel with RON higher than 95 such knocking has been decreased, and by using direct injection system with two injection spray strategy in the area of lean mixture, $\lambda>1$ such knoking will be eliminated.

Intelligent valve will be subject to novelty has been register for patent pending allows air to fill the combustion chamber in lean mixture based on the ECU input from the throttle. The air is supplied through turbocharger to make sure certain amount of air fill up the combustion chamber under pressure.

In the next work, some detail technical data will be presented as it goes to zero series production and application.

\section{References}

[1] Harianton, I., Ruswandi, A., Nurdin, M. (2014). "Design of a New Ecological Combustion Engine with Double Potential Power Output", International Journal Applied Mechanics and Materials Volumes. 465-466, pp 428-432.

[2] Pischinger, R. and Klell, M. (2008), Jenbacher Energy Systems, Institute for Internal Combustion Engines and Thermodynamics, Technical University Graz, Austria. p. 9-29.

[3] Yilmar H., Miersch-Wiemers O., Jiang L., Sterniak J. (2014), Advanced Combustion Concepts - Enabling Systems and Solutions (ACCESS), DOE Technology Development, Farmington Hill, MI 48331.

[4] Rakowski S., Eckert P., Witt A., (2012). Combustion Engine Development: Mixture formation, Combustion, Emission and Simulation, Springer-Verlag Berlin - Heidelberg.

[5] R. Mikalsen and A.P. Roskilly (2008). The Design and Simulation of a Two-Stoke Free-piston Compression Ignition Engine for Electrical Power Generation, Applied Thermal Engineering, Volume 28, Issues 5-6, pp. 589-600.

[6] Harry B. Higley (1992), All About Engines, published by Harry B. Higley \& Sons, Inc, Glenwood, Illinois 60425.

[7] David C. Gierke (1994), "2-Stroke Glow Engines For R/C Aircraft", Volume 1, Publisher Air Age, Inc, 251 Danbury Rd, Wilton, CT 06897, ISBN:0-911295-30-5.

[8] Kolmanovsky, I.V (2009), U.S. Patent 7,562,530 B2.

[9] Michelini, J., Kolmanovsky, I.V., and Gibson, A (2010), U.S. Patent 7730870.

[10] Michelini, J., and Kolmanovsky, I.V (2008), U.S. Patent $7,464,674 \mathrm{~B} 2$.

[11] Kolmanovsky, I.V., Song, G., Michelini, J. (2009), U.S. Patent $7,565,899$ B2.

[12] Kolmanovsky, I.V., Gibson, A., and Lewis, D. (2012), US. Patent 8,141,358.

[13] Gibson, A., Kolmanovsky, I.V., Michelini, J., and Song, G. (2010), U.S. Patent 7,809,492.

[14] Sun, J., and Kolmanovsky, I.V. (2004), U.S. Patent 6,805,095.

[15] Lamas G., V. Rodriguez (2012), Simulation of Scavenging Process of Two Stroke Engine, Universidad da Corune, Spain. 